\title{
Frank's sign in recurrent triple-vessel disease
}

\author{
Ryohei Ono (ㄷ), Togo Iwahana, Yoshio Kobayashi
}

Department of Cardiovascular Medicine, Chiba University Graduate School of Medicine, Chiba, Japan

\section{Correspondence to} Dr Ryohei Ono;

ryohei_ono_0820@yahoo.co.jp

Accepted 9 September 2020

\section{DESCRIPTION}

A 78-year-old man with hypertension, diabetes and dyslipidaemia presented with acute chest pain, following a history of myocardial infarction 11 years ago. Percutaneous coronary intervention was performed to implant bare-metal stents in the stenotic right coronary artery, left anterior descending artery and left circumflex coronary artery (figure 1A,B). A follow-up coronary angiography 10 years ago showed no significant stenosis (figure 1C,D).

On arrival, his vital signs were stable and physical examination revealed Frank's sign, a diagonal crease in the earlobe that runs backward from the tragus at a $45^{\circ}$ angle across the lobule to the rear edge of the auricle (figure 2). A coronary angiography showed the triple-vessel disease again (figure 1E,F). He subsequently underwent coronary artery bypass graft surgery and he was relieved from the chest pain. Frank's sign was first described by Frank in $1973 .{ }^{1}$ It is associated with cardiovascular risk factors and is originally described to predict coronary artery disease. ${ }^{2}$ A 35 -year-long large population prospective study revealed visible age-related signs such as Frank's sign, male pattern

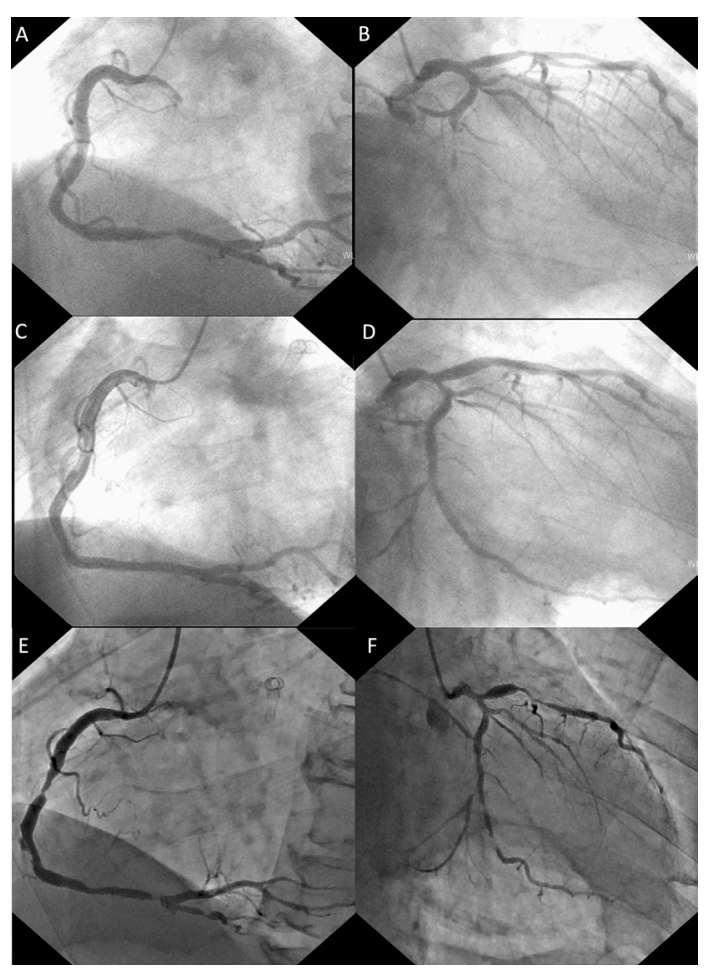

Figure 1 (A, B) Preoperative coronary angiography showing triple-vessel disease. (C, D) Follow-up coronary angiography after percutaneous coronary intervention showing no significant stenosis. (E, F) Present coronary angiography showing triple-vessel disease recurrence.

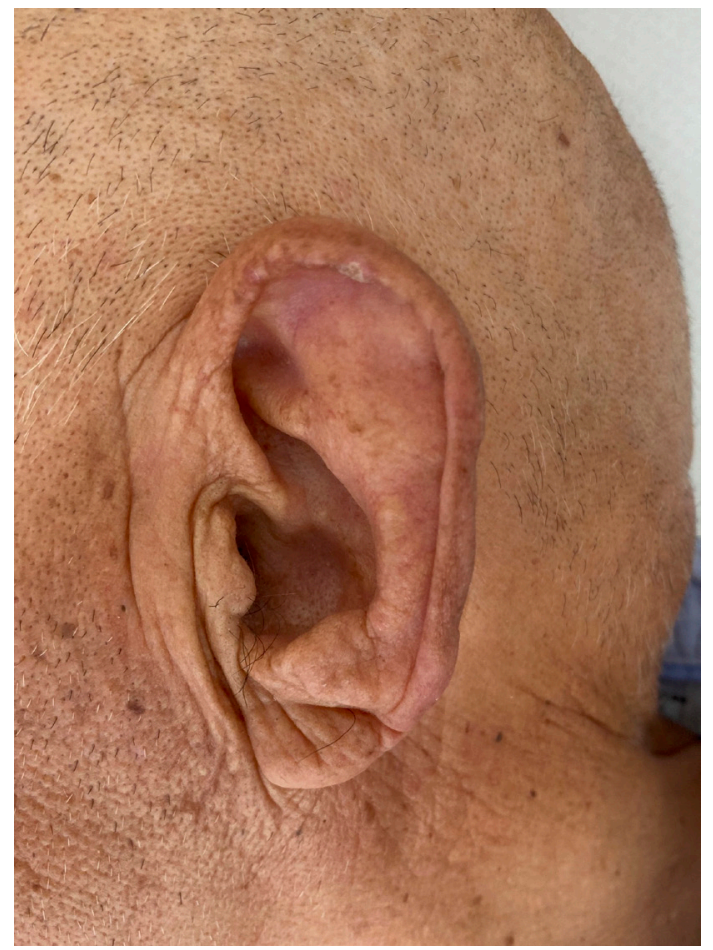

Figure 2 Bilateral Frank's sign showing a diagonal crease in the earlobe that runs backward from the tragus at $a 5^{\circ}$ angle across the lobule to the rear edge of the auricle.

baldness and xanthelasmata, associated with increased risk of ischaemic heart disease independent of chronological age and other cardiovascular risk factors. ${ }^{2}{ }^{3}$ Frank's sign in patients less than 60 years of age is reported as a useful diagnostic physical examination since the prevalence of diagonal ear lobe crease increases with age, as does coronary artery disease. ${ }^{45}$ Earlobe inspection to elicit Frank's sign is, hence, crucial in predicting atherosclerotic disease. $^{6}$

And true enough, coronary angiography revealed recurrence of triple-vessel disease. This case indicates that Frank's sign can be a clue to identify even triple-vessel disease.

\section{Learning points}

- Franks's sign is associated with cardiovascular risk factors.

- Earlobe inspection to elicit Frank's sign is crucial in predicting atherosclerotic disease.

- Frank's sign can be a clue to identify even triplevessel disease. 
Contributors RO contributed to conception and design, drafting the article and was involved in management of the case. TI and YK contributed to final critical appraisal of the article and were involved in management of the case.

Funding The authors have not declared a specific grant for this research from any funding agency in the public, commercial or not-for-profit sectors.

Competing interests None declared.

Patient consent for publication Obtained.

Provenance and peer review Not commissioned; externally peer reviewed.

\section{ORCID iD}

Ryohei Ono http://orcid.org/0000-0002-4875-7470

\section{REFERENCES}

1 Frank ST. Aural sign of coronary-artery disease. N Engl J Med 1973;289:327-8.

2 Christoffersen M, Frikke-Schmidt R, Schnohr P, et al. Visible age-related signs and risk of ischemic heart disease in the general population: a prospective cohort study. Circulation 2014;129:990-8.

3 Mallinson T, Brooke D. Frank's sign as a clinical marker of cardiovascular disease. Journal of Paramedic Practice 2017;9:8-10.

4 Xu R, Pham J. Frank's sign: a coronary artery disease predictor. BMJ Case Rep 2014;2014. doi:10.1136/bcr-2014-205770. [Epub ahead of print: 15 Jul 2014].

5 Fabijanić D, Čulić V. Diagonal ear lobe crease and coronary artery disease. Am J Cardiol 2012;110:1385-6

6 Aizawa T, Shiomi H, Kitano K, et al. Frank's sign: diagonal earlobe crease. Eur Heart J 2018;39:3653.

Copyright 2020 BMJ Publishing Group. All rights reserved. For permission to reuse any of this content visit

https://www.bmj.com/company/products-services/rights-and-licensing/permissions/

BMJ Case Report Fellows may re-use this article for personal use and teaching without any further permission.

Become a Fellow of BMJ Case Reports today and you can:

- Submit as many cases as you like

- Enjoy fast sympathetic peer review and rapid publication of accepted articles

- Access all the published articles

Re-use any of the published material for personal use and teaching without further permission

\section{Customer Service}

If you have any further queries about your subscription, please contact our customer services team on +44 (0) 2071111105 or via email at support@bmj.com.

Visit casereports.bmj.com for more articles like this and to become a Fellow 